\title{
Младен Кецман
}

Факултет спорта и физичког васпитања, Универзитет у Београду

УДК 796.8.093.1, 796.8.015.8:796.032.2“2012“

\section{КОМПАРАЦИЈА ТАКМИЧАРСКЕ АКТИВНОСТИ РВАЧА ГРЧКО-РИМСКИМ И СЛОБОДНИМ СТИЛОМ НА ОЛИМПИЈСКИМ ИГРАМА У ЛОНДОНУ 2012. ГОДИНЕ}

\begin{abstract}
Сажетак
Предмет овог рада је такмичарска активност рвача грчко-римским и слободним стилом. Такмичарска активност је анализирана на узорку свих борби које су одржане на Олимпијским играма у Лондону 2012. године, а које су реализоване у 7 тежинских категорија. На основу ових борби могуће је добити јасан увид у физиономију такмичарске активности у рвању грчко-римским и слободним стилом, уочити разлике између показатеља такмичарске активности у ова два стила рвања, те посебно издвојити специфичности за сваки од ова два стила рвања. При одређивању предмета рада пошло се од чињенице да ток и динамика борбе зависе од: правила борбе, али и начина примене тих правила, броја и врсте техника, временских параметара у којима се техника изводи, динамике додељивања казни и казнених поена, те умешности у кориштењу могућности провере исправности одлука које су донели судије. Циљ истраживања је да се упореди такмичарска активност рвача у грчко-римском и у слободном стилу рвања те да се на основу тих показатеља дефинишу показатељи на које такмичарска дисциплина нема битнијег утицаја, као и да се јасно профилишу показатељи такмичарске активности који се значајно разликују у ове две дисциплине. Све ово требало би да скрене пажњу спортским стручњацима у рвачком спорту на показатеље такмичарске активности који су специфични за сваку од ове две такмичарске дисциплине и тиме дају својеврсне смернице за тренажну технологију. Прикупљање података, у овом истраживању трансверзалног карактера, извршено је методом опсервације, тј. анализом података са такмичења при чему је коришћен видео материјал свих борби на Олимпијским играма у Лондону 2012. године.
\end{abstract}

КљУчне речи: СЕДАМ ТЕЖИНСКИХ КАТЕГОРИЈА / РАЗЛИКЕ ИЗМЕЂУ ДВЕ ДИСЦИПЛИНЕ 


\title{
THE COMPARISON OF THE COMPETITIVE ACTIVITY OF WRESTLERS IN GRECO- ROMAN AND FREESTYLE AT THE OLYMPIC GAMES IN LONDON IN 2012
}

\begin{abstract}
Summary
The subject of this study is the competitive activity of wrestlers in Greco-Roman and Freestyle. The competitive activity was analyses on the specimen of all fights held at the Olympic games in London in 2012, and realised in seven weight classes. Based on these fights, it is posible to get the clear insight in physionomy of competitive acivity in wrestling in both Greco-Roman and Freestyle, as well as particularly point out the specifity of both of these wresting styles. When defining the subject of the study we have started from the fact that the course and dynamics of the fight depend on: the rules of the fight, as well as the method of applying these rules, the number and type of techniques, time parameters the technique is performed in, dynamics of awarding penalties and penalty points, and also the skill in using the possibilities of checking the righteousness of decisions made by the judges. The goal of the research is to compare the competitive activity of wrestlers in Greco-Roman and Freestyle Wrestling and based on these indicators define indicators on which the competitive discipline hasn't got much influence. Also, the goal is to clearly create profiles of the competitive activity indicators that are highly different in these two disciplines. All of this should draw attention of sports experts in Wrestling to indicators of the competitive activity that are specific for each of these competitive disciplines and in that way give guidelines for training technology. In this research of transversal character, data gathering has been conducted through the observational method, i.e. based on the analisys of data from competitions by the help of the video material of all the fights held at the Olympic games in London 2012.
\end{abstract}

Key words: SEVEN WEIGHT CATHEGORIES / DIFFERENCES BETWEEN TWO DISCIPLINES 


\section{1. Увод}

Честе промене правила доводе до отежавања компарирања резултата са великих светских такмичења кроз један дужи низ година. Данас се разним методама обраде и анализе података и ови проблеми превазилазе, тако да постоје и дугорочне анализе великих светских такмичења, са посебним нагласком на поједине сегменате рвачке борбе (време трајања борбе, остварени бодови, техника која се изводи...). У том циљу, врши се компарација резултата са различитих такмичења, а на основу резултата компаративне анализе могуће је добити егзактне показатеље о свим битним елементима једне борбе, комплетног такмичења, али и показатеље по различитим тежинским категоријама. Напредак у квалитету обраде ових информација значајно доприноси и рационалнијем приступу планирања и програмирања тренажног процеса.

Како би се поспешило постизање врхунских резултата, неопходно је користити нова научна сазнања у раду са врхунским рвачима, младим и талентованим спортистима. Једна од ствари које су најбитније за планирање и програмирање тренажног процеса у спорту јесте анализа такмичења, односно такмичарске активности, а потуно је јасно да највећу употребну вредност има анализа највећих светских такмичења: светских и континенталних првенстава и олимпијских игара. Управо због тога, овај рад представља покушај да се да допринос бољем сагледавању и разумевању такмичарске активности у рвачком спорту.

\section{2. Методологија истраживања}

Прикупљање података, у овом истраживању трансверзалног карактера, извршено је методом опсервације, тј. анализом података са такмичења при чему је коришћен видео материјал свих борби на Олимпијским играма у Лондону 2012. године. 


\section{1. Узорак}

Узорак истраживања предстаљају све борбе које су, на Олимпијским играма у Лондону 2012. године, одржане у рвању грчко-римским и слободним стилом за мушкарце, укупно 316 борби. У грчко-римском стилу је учествовало 135 такмичара, а одржано је и обрађено укупно 159 борби, док је у слободном стилу учествовало 133 такмичара, а одржано је и обрађено 157 борби.

На Олимпијским играма у Лондону учествовало је укупно 268 рвача из 60 земаља света, подељених у 7 тежинских категорија: $55 \mathrm{~kg}, 60 \mathrm{~kg}, 66 \mathrm{~kg}, 74 \mathrm{~kg}, 84 \mathrm{~kg}, 96 \mathrm{~kg}$ и до $120 \mathrm{~kg}$.

Прикупљање података извршено је документационом методом тј. анализом података са такмичења при чему је главну улогу имао видео запис комплетног такмичења.

Истраживањем су обухваћене све одржане борбе у свим тежинским категоријама, тј. све технике и сви елементи борбе, као и број остварених бодова. Олимпијске игре су одржане по систему директне елиминације до финала, док су могућност за освајање две бронзане медаље добијали рвачи који су поражени од финалиста. У свакој категорији наступило је по 20 такмичара који су се, кроз систем квалификација, изборили за право учешћа на овом такмичењу.

\section{2. Варијабле}

Предикторске варијабле овог истраживања представљају неке од типичних показатеља такмичарске активности које се односе на трајање борбе, укупну бодовну вредност и фреквенцију поентирајућих техника, број поена направљених у стојећем ставу и у партеру, број јавних опомена, начин победе, док су критеријумске варијабле представљене такмичарском дисциплином.

Критеријумске варијабле:

* грчко-римски стил

* слободан стил

Предикторске варијабле:

УТБ - укупно трајање борбе

УБП - укупан број поена

БПР - број поена по рундама

УБПСС - укупан број поена, стојећи став

УБПП - укупан број поена, партер

КН - клинч напад

КО - клинч одбрана

ОПН - обавезни партер, напад

ОПО - обавезни партер, одбрана

ОСП - опомена из старта у партеру

ПТ - победе тушем

ПТТ - победе техничким тушем 
ПНП - победа на поене

ПП - победа прекидом

ИБ - интензитет борбе

БЧ - бод из челенџа

БВА1 - број акција од 1 поена

БВА2 - број акција од 2 поена

БВАЗ - број акција од 3 поена

БВА5 - број акција од 5 поена

\section{3. Методе анализе резултата}

У овој студији коришћене су дескриптивне и аналитичке статистичке методе. Од дескриптивних, коришћени су апсолутни и релативни бројеви (n, \%), мере централне тенденције (аритметичка средина, медијана) и мере дисперзије (стандардна девијација и интервал варијације). Од аналитичких статистичких метода коришћени су тестови разлике, параметарски и непараметарски. Параметарски тест коришћен у овој студији је т тест за независне узорке, док је од непараметарских тестова коришћен Хиквадрат тест и Ман-Витнијев У тест. Резултати су приказани табеларно и графички. Сви подаци обрађени су у SPSS 20.0 (ИБМ корпорација ) у софтверском пакету.

\section{3. Резултати истраживања са дискусијом}

Овим истраживањем обухваћено је укупно 315 борби. Од укупног броја борби, 159 (50.5\%) су биле борбе у грчко-римском стилу, док је у слободном стилу одржано 156 борби (49.5\%). 


\section{ПРЕДАТЕ БОРБЕ}

У табели 1 приказана је дистрибуција борби по стиловима у односу на предате борбе које нису ни одржане.

Табела 1: Предате борбе по стиловима

\begin{tabular}{|c|c|c|c|c|c|}
\hline & & & \multicolumn{2}{|c|}{ Предате борбе } & \multirow{2}{*}{ Укупно } \\
\hline & & & $\mathrm{He}$ & Да & \\
\hline \multirow{6}{*}{ Стил } & \multirow{2}{*}{ ГРЧКО-РИМСКИ } & $\mathrm{N}$ & 159 & 0 & 159 \\
\hline & & $\%$ & $100.0 \%$ & $0.0 \%$ & $100.0 \%$ \\
\hline & \multirow{2}{*}{ СЛОБОдни } & $\mathrm{N}$ & 148 & 8 & 156 \\
\hline & & $\%$ & $94.9 \%$ & $5.1 \%$ & $100.0 \%$ \\
\hline & \multirow[b]{2}{*}{ Укупно } & $\mathrm{N}$ & 307 & 8 & 315 \\
\hline & & $\%$ & $97.5 \%$ & $2.5 \%$ & $100.0 \%$ \\
\hline
\end{tabular}

Све борбе у којима је победа остварена предајом једног од бораца забележене су у слободном стилу (Табела 1). Анализирајући ове податке Хи-квадрат тестом утврђено је да су разлике између ова два стила по броју предатих борби статистички значајне $(\mathrm{X} 2=8.366 ; \mathrm{p}=0.003)$.

Све борбе које нису одржане, предате су због повреде, што доводи до тога да стил борбе значајно утиче на број повреда у борбама овог типа те да се, због специфичности захвата и покрета у слободном стилу, повећава и могућност од повреда.

Предате борбе биле су у категоријама $55 \mathrm{~kg}$ (1 борба), 66kg (2 борбе), 84kg (1 борба) и 96kg (4 борбе)

Пошто би укључивање у анализу ових 8 неодржаних борби значајно пореметило објективну представу о показатељима такмичарске активности, у предстојећим анализама искључено је ових 8 борби које су завршене предајом. У том случају, дистрибуција је нешто другачија и сада је 159 (51.8\%) борби било грчко-римским стилом, док је 148 (48.2\%) било слободним стилом.

\section{БОдОвИ}

Урађена је анализа бодовања код свих борби као и у односу на стил борбе. Прво је приказано бодовање у зависности од тога колико је бодова дато, а онда су приказани сумарно бодови за сваку рунду посебно. 
Дистрибуција борби у односу на број акција у првој рунди које су бодоване 1 бодом приказана је у табели 2.

Табела 2: Број остварених акиија за 1 бод у рунди 1

\begin{tabular}{|c|c|c|c|c|c|c|c|c|}
\hline & & \multicolumn{6}{|c|}{ БВА1 у рунди 1} & \multirow{2}{*}{ Укупно } \\
\hline & & 0 & 1 & 2 & 3 & 4 & 5 & \\
\hline \multirow{2}{*}{$\begin{array}{l}\text { ГРЧКО- } \\
\text { РИМСКИ }\end{array}$} & $\mathrm{H}$ & 41 & 96 & 17 & 3 & 2 & 0 & 159 \\
\hline & $\%$ & $25.8 \%$ & $60.4 \%$ & $10.7 \%$ & $1.9 \%$ & $1.3 \%$ & $0.0 \%$ & $100.0 \%$ \\
\hline \multirow{2}{*}{ сЛОБОДНИ } & $\mathrm{H}$ & 10 & 82 & 30 & 13 & 10 & 3 & 148 \\
\hline & $\%$ & $6.8 \%$ & $55.4 \%$ & $20.3 \%$ & $8.8 \%$ & $6.8 \%$ & $2.0 \%$ & $100.0 \%$ \\
\hline \multirow{2}{*}{ Укупно } & $\mathrm{H}$ & 51 & 178 & 47 & 16 & 12 & 3 & 307 \\
\hline & $\%$ & $16.6 \%$ & $58.0 \%$ & $15.3 \%$ & $5.2 \%$ & $3.9 \%$ & $1.0 \%$ & $100.0 \%$ \\
\hline
\end{tabular}

У оба стила најчешће је током прве рунде један бод додељиван једном у целој рунди, и то у грчкоримском стилу у $60.4 \%$ борби, а у слободном стилу у $55.4 \%$ борби. У грчко-римском стилу има доста борби у којима током прве рунде уопште није додељен 1 бод (25.8\% борби), док је број борби у којима је 1 бод додељен више од једном пуно ређи, па је један бод по 2 пута досуђен у 10.7\% борби, 3 пута у $1.9 \%$ борби, а 4 пута у 1.3\% борби. У слободном стилу, прва рунда је без акције за 1 бод завршена у само $6.8 \%$ борби, али је знатно више борби у којима је у првој рунди 1 бод досуђен више од једанпут, тако да је један бод досуђен 2 пута у $20.3 \%$ борби, 3 пута у $8.8 \%$ борби, 4 пута у $6.8 \%$ борби, док је у $2 \%$ борби 1 бод досуђен чак 5 пута. У просеку, 1 бод је у грчко-римском стилу дат $0.92 \pm 0.74$ пута (медијана 1$)$ док је у слободном стилу дат у просеку $1.59 \pm 1.09$ пута (медијана 1$)$.

Анализирајући ове резултате Ман-Витнијевим У тестом утврђено је да постоји статистички значајна разлика између ова два стила у освајању једног бода у првој рунди ( $3=-6.026 ; \mathrm{p}<0.001)$.

Рунда 1 - акције за 2 бода - БВА2

Из табеле 3 се види да је у првој рунди више борби без акције за два бода забележено у слободном стилу него у грчко-римском, али је зато број борби у којима је једном дато два бода био већи у грчко-римском стилу. 
Табела 3 Освајање 2 бода у првој рунди по стиловима

\begin{tabular}{|c|c|c|c|c|c|c|}
\hline & & \multicolumn{4}{|c|}{ БВА2 у рунди 1} & \multirow{2}{*}{ Укупно } \\
\hline & & 0 & 1 & 2 & 3 & \\
\hline \multirow{2}{*}{$\begin{array}{l}\text { ГРЧКО- } \\
\text { РИМСКИ }\end{array}$} & $\mathrm{H}$ & 101 & 51 & 7 & 0 & 159 \\
\hline & $\%$ & $63.5 \%$ & $32.1 \%$ & $4.4 \%$ & $0.0 \%$ & $100.0 \%$ \\
\hline \multirow{2}{*}{ слОБОДНИ } & $\mathrm{H}$ & 109 & 26 & 10 & 3 & 148 \\
\hline & $\%$ & $73.6 \%$ & $17.6 \%$ & $6.8 \%$ & $2.0 \%$ & $100.0 \%$ \\
\hline \multirow{2}{*}{ Укупно } & $\mathrm{H}$ & 210 & 77 & 17 & 3 & 307 \\
\hline & $\%$ & $68.4 \%$ & $25.1 \%$ & $5.5 \%$ & $1.0 \%$ & $100.0 \%$ \\
\hline
\end{tabular}

Током прве рунде, у оба стила, уопште није било акција за 2 бода, а то је случај био у 101 борби у грчкоримском и у 109 борби у слободном стилу (Табела 3). Током прве рунде, два бода су у грчко-римском стилу досуђена по једном у $32.1 \%$ борби, док су у слободном стилу током прве рунде два бода једном досуђена у $17.6 \%$ борби. Може се констатовати да у грчко-римском стилу има пуно борби у којима током прве рунде уопште нису додељена 2 бода (63.5\% борби), док је број борби у којима су 2 бода додељена више од једанпут пуно ређи (2 пута у 4.4\% борби док акција за 2 бода 3 пута у ниједној борби). У слободном стилу, прва рунда је завршена без акције за 2 бода у $73.6 \%$ борби, али је знатно мање борби у којима је, у првој рунди, 2 бод додељиван више од једанпут (2 пута у $6.8 \%$ борби, 3 пута у $2.0 \%$ борби).

Просечно, у грчко-римском стилу су у првој рунди 2 бода досуђена $0.41 \pm 0.57$ пута (медијана 0 ), док је акција за 2 бода у слободном стилу досуђена $0.37 \pm 0.70$ пута по борби (медијана 0 ).

Анализирајући ове податке Ман-Витнијевим У тестом утврђено је да у броју акција које су са два бода бодоване у првој рунди не постоје статистички значајне разлике између стилова $(\mathrm{Z}=-1.485 ; \mathrm{p}=0.138)$. 
Рунда 1 - акције за 3 бода - БВАЗ

Дистрибуција борби у којој је досуђено три бода приказана је табеларно (Табела 4).

Табела 4 Освајање 3 бода у првој рунди по стиловима

\begin{tabular}{|c|c|c|c|c|c|c|}
\hline & & & \multicolumn{3}{|c|}{ БВАЗ у рунди 1} & \multirow{2}{*}{ Укупно } \\
\hline & & & 0 & 1 & 2 & \\
\hline \multirow{4}{*}{ Стил } & \multirow{2}{*}{$\begin{array}{l}\text { ГРЧКО- } \\
\text { РИМСКИ }\end{array}$} & $\mathrm{H}$ & 144 & 14 & 1 & 159 \\
\hline & & $\%$ & $90.6 \%$ & $8.8 \%$ & $0.6 \%$ & $100.0 \%$ \\
\hline & \multirow{2}{*}{ сЛОБОДНИ } & $\mathrm{H}$ & 128 & 20 & 0 & 148 \\
\hline & & $\%$ & $86.5 \%$ & $13.5 \%$ & $0.0 \%$ & $100.0 \%$ \\
\hline \multirow{2}{*}{\multicolumn{2}{|c|}{ Укупно }} & $\mathrm{H}$ & 272 & 34 & 1 & 307 \\
\hline & & $\%$ & $88.6 \%$ & $11.1 \%$ & $0.3 \%$ & $100.0 \%$ \\
\hline
\end{tabular}

Из табеле се види да су проценти у оба стила врло слични и да је три бода у оба стила досуђивано врло сличном учесталошћу. Током прве рунде у оба стила, најчешће уопште нису забележена 3 бода. По једном у целој рунди три бода су грчко-римском стилу досуђена у $8.8 \%$ борби, а у слободном стилу у $13.5 \%$ борби. У грчко-римском стилу има доста борби у којима током прве рунде уопште нису додељена 3 бода чак $90.6 \%$ борби, док су 3 бода више од једном додељена у само једној борби. У слободном стилу, чак $86.5 \%$ борби током прве рунде није имало акције за 3 бода, док 3 бода више од једанпут нису досуђена ни у једној борби.

У просеку, три бода су, у првој рунди, у грчко-римском стилу, давана $0.10 \pm 0.32$ пута по борби (медијана 0 ), а у слободном стилу нешто чешће, $0.14 \pm 0.34$ пута по борби (медијана 0 ).

Анализирајући ове податке Ман-Витнијевим У тестом утврђено је да нема статистички значајне разлике између стилова по добијању три бода у рунди $1(\mathrm{Z}=-1.098 ; \mathrm{p}=0.272)$. 
Рунда 1 - акције за 5 бодова - БВА5

Дистрибуција борби по стиловима у односу на добијених 5 бодова у рунди 1 приказана је у табели 5 .

Табела 5 Освајање 5 бодова у првој рунди по стиловима

\begin{tabular}{|c|c|c|c|c|c|}
\hline & & & \multicolumn{2}{|c|}{ БВА5 у рунди 1} & \multirow{2}{*}{ Укупно } \\
\hline & & & 0 & 1 & \\
\hline \multirow{4}{*}{ Стил } & \multirow{2}{*}{$\begin{array}{l}\text { ГРЧКО- } \\
\text { РИМСКИ }\end{array}$} & $\mathrm{H}$ & 158 & 1 & 159 \\
\hline & & $\%$ & $99.4 \%$ & $0.6 \%$ & $100.0 \%$ \\
\hline & \multirow{2}{*}{ СЛОБОДНИ } & $\mathrm{H}$ & 148 & 0 & 148 \\
\hline & & $\%$ & $100.0 \%$ & $0.0 \%$ & $100.0 \%$ \\
\hline \multirow{2}{*}{\multicolumn{2}{|c|}{ Укупно }} & $\mathrm{H}$ & 306 & 1 & 307 \\
\hline & & $\%$ & $99.7 \%$ & $0.3 \%$ & $100.0 \%$ \\
\hline
\end{tabular}

Већ на први поглед се уочава да је, током прве рунде, 5 бодова досуђено само једном и то у грчкоримском стилу, што је јасан показатељ да у првој рунди није било атрактивних бацања великом амплитудом (табела 5).

Анализирајући ове податке утрђено је да нема статистички значајни разлике између стилова у броју остварених бацања за пет бодова ( $\mathrm{p}=1.000)$.

Укупан број бодова у рунди 1 - БПР1

На основу добијених бодова урађена је статистика укупног броја бодова по стиловима, а дескриптивна статистика приказана је у табели 6 .

Табела 6 Укупан број бодова у првој рунди

\begin{tabular}{lcccccc}
\hline \hline Стил & $\begin{array}{l}\text { Аритметичка } \\
\text { средина }\end{array}$ & СД & Медиан & Минимум & Максимум & Сума \\
\hline $\begin{array}{l}\text { ГРЧКО- } \\
\text { РИМСКИ }\end{array}$ & 2.08 & 1.343 & 2.00 & 1 & 7 & 330 \\
СЛОБОДНИ & 2.74 & 2.077 & 2.00 & 1 & 11 & 406 \\
Укупно & 2.40 & 1.765 & 2.00 & 1 & 11 & 736 \\
\hline \hline
\end{tabular}

Из табеле се види да је у слободном стилу остварен већи број бодова (и укупно и просечно по борби), али је исто тако и варирање веће у истом стилу. Медијане су једнаке, док је сума бодова евидентно већа у слободном стилу. У грчко-римском стилу је укупно остварено 330 бодова док је у слободном стилу освојено доста више 406 бодова. Минималан број остварених бодова је подједнак у оба стила и износи 1 
бод, док је максималан број бодова остварених у првој рунди у грчко-римском стилу износио 7, док је у слободном стилу максималан број бодова у првој рунди износио 11.

Ман-Витнијевим У тестом потврђено је да постоји статистички значајна разлика између стилова у укупном броју бодова у првој рунди $(Z=-2.449 ; \mathrm{p}=0.014)$.

Рунда 2 - акције за 1 бод - БВА1

Дистрибуција борби по стиловима у односу на 1 бод досуђен у рунди 2 приказана је у табели 7.

Табела 7 Освајање 1 бода у другој рунди по стиловима

\begin{tabular}{|c|c|c|c|c|c|c|c|c|c|c|c|}
\hline & & & \multicolumn{8}{|c|}{ БВА1 у рунди 2} & \multirow{2}{*}{ Укупно } \\
\hline & & & 0 & 1 & 2 & 3 & 4 & 5 & 6 & 7 & \\
\hline \multirow{4}{*}{ Стил } & \multirow{2}{*}{$\begin{array}{l}\text { ГРЧКО- } \\
\text { РИМСКИ }\end{array}$} & $\mathrm{H}$ & 28 & 106 & 22 & 3 & 0 & 0 & 0 & 0 & 159 \\
\hline & & $\%$ & $17.6 \%$ & $66.7 \%$ & $13.8 \%$ & $1.9 \%$ & $0.0 \%$ & $0.0 \%$ & $0.0 \%$ & $0.0 \%$ & $100.0 \%$ \\
\hline & \multirow{2}{*}{ СЛОБОДНИ } & $\mathrm{H}$ & 5 & 63 & 41 & 25 & 9 & 3 & 1 & 1 & 148 \\
\hline & & $\%$ & $3.4 \%$ & $42.6 \%$ & $27.7 \%$ & $16.9 \%$ & $6.1 \%$ & $2.0 \%$ & $0.7 \%$ & $0.7 \%$ & $100.0 \%$ \\
\hline \multirow{2}{*}{\multicolumn{2}{|c|}{ Укупно }} & $\mathrm{H}$ & 33 & 169 & 63 & 28 & 9 & 3 & 1 & 1 & 307 \\
\hline & & $\%$ & $10.7 \%$ & $55.0 \%$ & $20.5 \%$ & $9.1 \%$ & $2.9 \%$ & $1.0 \%$ & $0.3 \%$ & $0.3 \%$ & $100.0 \%$ \\
\hline
\end{tabular}

На основу дистрибуције из табеле 7 се види да је и током друге рунде, најчешће, у оба стила један бод досуђиван једанпут. Један бод је далеко чешће потпуно изостао у грчко-римском стилу (у 28 борби) него у слободном стилу, где је то случај био у свега 5 борби. Најчешће је током друге рунде, у оба стила, један бод додељиван једном у целој рунди, у грчко-римском стилу у $66.7 \%$ борби, а у слободном стилу у $42.6 \%$ борби. У грчко-римском стилу има доста борби у којима током друге рунде уопште није додељен 1 бод (17.6\% борби), док је број борби у којима је 1 бод додељен више од једанпут пуно ређи (2 пута у $13.8 \%$ борби, 3 пута у 1.9\% борби). У слободном стилу, друга рунда је без акције за 1 бод завршена у само $3.4 \%$ борби, али је знатно више борби у којима је 1 бод додељиван више од једанпут (2 пута у $27.7 \%$ борби, 3 пута у 16.9\% борби, 4 пута у 6.1\% борби, а у 2\% борби 1 бод је додељен чак 5 пута и 6 и 7 пута по једном $0.7 \%$ ).

У просеку, један бод је у другој рунди дат $1.00 \pm 0.62$ пута по борби (медијана 1) у грчко-римском стилу, док је $1.92 \pm 1.19$ пута (медијана 2) дат у слободном стилу. Анализирајући ове податке Ман-Витнијевим У тестом утврђено је да се број акција за 1 поен у другој рунди статистички значајно разликује у грчкоримском и слободном стилу $(Z=-7.825 ; \mathrm{p}<0.001)$

Дистрибуција борби по стиловима у односу на два бода освојена у другој рунди приказана је у табели 8. 
Табела 8 Освајање 2 бода у другој рунди по стиловима

\begin{tabular}{|c|c|c|c|c|c|c|c|}
\hline & & & \multicolumn{4}{|c|}{ БВА2 у рунди 2} & \multirow{2}{*}{ Укупно } \\
\hline & & & 0 & 1 & 2 & 3 & \\
\hline \multirow{4}{*}{ Стил } & \multirow{2}{*}{$\begin{array}{l}\text { ГРЧКО- } \\
\text { РИМСКИ }\end{array}$} & $\mathrm{H}$ & 124 & 34 & 1 & 0 & 159 \\
\hline & & $\%$ & $78.0 \%$ & $21.4 \%$ & $0.6 \%$ & $0.0 \%$ & $100.0 \%$ \\
\hline & \multirow{2}{*}{ СЛОБОДНИ } & $\mathrm{H}$ & 102 & 34 & 9 & 3 & 148 \\
\hline & & $\%$ & $68.9 \%$ & $23.0 \%$ & $6.1 \%$ & $2.0 \%$ & $100.0 \%$ \\
\hline \multirow{2}{*}{\multicolumn{2}{|c|}{ Укупно }} & $\mathrm{H}$ & 226 & 68 & 10 & 3 & 307 \\
\hline & & $\%$ & $73.6 \%$ & $22.1 \%$ & $3.3 \%$ & $1.0 \%$ & $100.0 \%$ \\
\hline
\end{tabular}

Из табеле се види да је дистрибуција слична, с тим да су два бода више пута изостала у грчко-римском него у слободном стилу. Најчешће су током друге рунде, у оба стила, два бода додељивана једном у целој рунди, у грчко-римском стилу у $21.4 \%$ борби, а у слободном стилу у $23 \%$ борби. У грчко-римском стилу има доста борби у којима током друге рунде уопште нису додељена 2 бода (78\% борби), док је број борби у којима су 2 бода додељена више од једанпут пуно ређи (то се десило у само једној борби). У слободном стилу, друга рунда је без акције за 2 бода завршена у $68.9 \%$ борби, али више борби у којима су 2 бода додељивана више од једанпут (2 пута у $6.1 \%$ борби, 3 пута у $2 \%$ борби).

У просеку, у другој рунди два бода су у грчко-римском стилу дата $0.23 \pm 0.43$ пута по борби (медијана 0 ), док су у слободном стилу, у просеку, два бода у другој рунди давана $0.41 \pm 0.69$ пута по борби (медијана 0). Анализирајући ове резултате Ман-Витнијевим У тестом, утврђено је да постоје статистички значајне разлике између стилова у броју акција за 2 поена у другој рунди $(Z=-2.103 ; p=0.035)$

Дистрибуција борби по стиловима у односу на дата 3 бода у другој рунди приказана је у табели 9.

Табела 9 Освајање 3 бода у другој рунди по стиловима

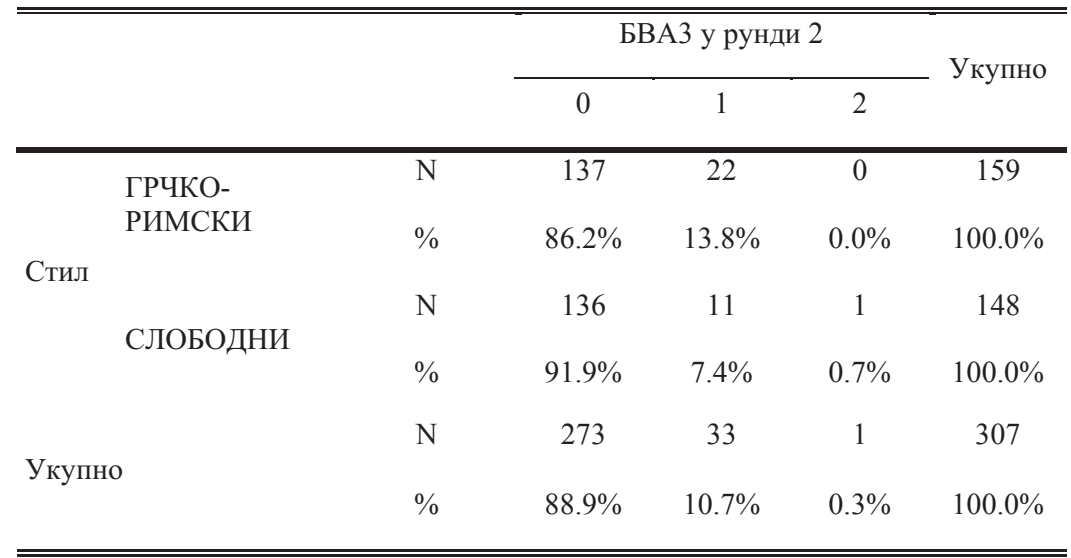


Из табеле се види да је дистрибуција бодовања у оба стила врло слична с тим да су три бода нешто чешће прављена у грчко-римском стилу. Током друге рунде, у оба стила, најчешће није било акција за 3 бода. Једном у рунди три бода су додељена у $13.8 \%$ борби (грчко-римски стил), а у слободном стилу у $11 \%$ борби. У грчко-римском стилу има доста борби у којима током друге рунде уопште нису додељена 3 бода (86.2\% борби), а нема борби у којима су 3 бода додељена више од једанпут. У слободном стилу, друга рунда је завршена без акције за 3 бода у $91.9 \%$ борби, а само у једној борби је у првој рунди 3 бода бодовано више од једанпут ( $0.7 \%$ борби).

У просеку, три бода су у другој рунди дата $0.14 \pm 0.34$ пута (медијана 0 ) када је у питању грчко-римски стил, док је у слободном стилу, у просеку, три бода у другој рунди бодовано $0.09 \pm 0.30$ пута по борби (медијана 0). Анализирајући ове резултате Ман-Витнијевим У тестом утврђено је да нема статистички значајне разлике између стилова $(\mathrm{Z}=-1.569 ; \mathrm{p}=0.117)$.

Рунда 2 - акције за 5 бодова - БВА5

Аналогно претходним анализама приказана је дистрибуција борби по стиловима у односу на пет бодова датих у рунди 2 (Табела 10).

Табела 10 Освајање 5 бодова у другој рунди по стиловима

\begin{tabular}{|c|c|c|c|c|c|}
\hline & & & \multicolumn{2}{|c|}{ БВА5 у рунди 2} & \multirow{2}{*}{ Укупно } \\
\hline & & & 0 & 1 & \\
\hline \multirow{4}{*}{ Стил } & \multirow{2}{*}{$\begin{array}{l}\text { ГРЧКО- } \\
\text { РИМСКИ }\end{array}$} & $\mathrm{H}$ & 158 & 1 & 159 \\
\hline & & $\%$ & $99.4 \%$ & $0.6 \%$ & $100.0 \%$ \\
\hline & \multirow{2}{*}{ слОБОдни } & $\mathrm{H}$ & 147 & 1 & 148 \\
\hline & & $\%$ & $99.3 \%$ & $0.7 \%$ & $100.0 \%$ \\
\hline \multirow{2}{*}{\multicolumn{2}{|c|}{ Укупно }} & $\mathrm{H}$ & 305 & 2 & 307 \\
\hline & & $\%$ & $99.3 \%$ & $0.7 \%$ & $100.0 \%$ \\
\hline
\end{tabular}

Из табеле се види да се ради о готово идентичној дистрибуцији, а тестирањем је утврђено да нема статистички значајне разлике између стилова у броју акција бодованих са пет бодова у рунди 2 ( $\mathrm{p}=1.000)$. 
Дескриптивна статистика укупног броја бодова у рунди 2 приказана је у Табели 11.

Табела 11 Укупан број бодова у рунди 2

\begin{tabular}{lcccccc}
\hline \hline Стил & $\begin{array}{l}\text { Аритметичка } \\
\text { средина }\end{array}$ & СД & Медиан & Минимум & Максимум & Сума \\
\hline $\begin{array}{l}\text { ГРЧКО- } \\
\text { РИМСКИ }\end{array}$ & 1.90 & 1.284 & 1.00 & 1 & 8 & 302 \\
СЛОБОДНИ & 3.04 & 2.102 & 2.50 & 0 & 10 & 450 \\
Укупно & 2.45 & 1.817 & 2.00 & 0 & 10 & 752 \\
\hline \hline
\end{tabular}

Просечна вредност и медијана су већи у слободном стилу, као и сума бодова. Ипак, и варијабилитет је већи у слободном стилу, у односу на грчко-римски стил. У грчко-римском стилу је укупно остварено 302 бода док је у слободном стилу освојено доста више, тј. 450 бодова. Минималан број остварених бодова је сличан у оба стила, а износи 1 бод у грчко- римском стилу, док у слободном стилу износи 0 бодова. Максималан број бодова у другој рунди у грчко-римском стилу био је 8 , док је у слободном стилу био 10 бодова.

Анализирајући ове податке Ман-Витнијевим У тестом утврђено је да постоји статистички значајна разлика између стилова по броју бодова у рунди $2(\mathrm{Z}=-5.172 ; \mathrm{p}<0.001)$.

Аналогно анализи претходне две рунде анализирано је и бодовање у трећој рунди. Дистрибуција борби у односу на бодоване акције за један бод у трећој рунди приказана је у табели 12 .

табела 12 Освајање 1 бода у трећој рунди по стиловима

\begin{tabular}{|c|c|c|c|c|c|c|c|c|c|}
\hline & & & \multicolumn{6}{|c|}{ БВА1 у рунди 3} & \multirow{2}{*}{ Укупно } \\
\hline & & & 0 & 1 & 2 & 3 & 4 & 5 & \\
\hline \multirow{4}{*}{ Стил } & \multirow{2}{*}{$\begin{array}{l}\text { ГРЧКО- } \\
\text { РИМСКИ }\end{array}$} & $\mathrm{H}$ & 120 & 31 & 8 & 0 & 0 & 0 & 159 \\
\hline & & $\%$ & $75.5 \%$ & $19.5 \%$ & $5.0 \%$ & $0.0 \%$ & $0.0 \%$ & $0.0 \%$ & $100.0 \%$ \\
\hline & \multirow{2}{*}{ сЛОБОДНИ } & $\mathrm{H}$ & 105 & 18 & 14 & 6 & 3 & 2 & 148 \\
\hline & & $\%$ & $70.9 \%$ & $12.2 \%$ & $9.5 \%$ & $4.1 \%$ & $2.0 \%$ & $1.4 \%$ & $100.0 \%$ \\
\hline \multirow{2}{*}{\multicolumn{2}{|c|}{ Укупно }} & $\mathrm{H}$ & 225 & 49 & 22 & 6 & 3 & 2 & 307 \\
\hline & & $\%$ & $73.3 \%$ & $16.0 \%$ & $7.2 \%$ & $2.0 \%$ & $1.0 \%$ & $0.7 \%$ & $100.0 \%$ \\
\hline
\end{tabular}

Из табеле се види да између ова два стила у трећој рунди постоје одређене разлике када је у питању давање једног бода. Наиме, нешто чешће је један бод изостао у грчко-римском стилу (у 75.5\% борби), док је то у слободном стилу случај био у $70.9 \%$ борби. Слична ситуација је и са борбама у којима је у трећој рунди 1 бод досуђен по једном. Најчешће је током треће рунде, у оба стила, један бод додељиван једном у целој рунди - грчко-римском стилу у $19.5 \%$ борби, а у слободном стилу у $12.2 \%$ борби. Број борби у којима је 1 бод додељен више од једанпут је пуно ређи, у грчко-римском стилу је 2 пута додељен у само 8 борби (5\%), док је у слободном стилу током треће рунде 1 бод чешће додељиван више од 
једанпут (2 пута у 9.5\% борби, 3 пута у $4.1 \%$ борби, 4 пута у 2\% борби, а у $1.4 \%$ борби 1 бод је додељен чак 5 пута).

У просеку, један бод је у трећој рунди досуђен $0.30 \pm 0.55$ пута (медијана 0 ) у грчко-римском стилу, док је у слободном стилу један бод у трећој рунди досуђен $0.58 \pm 1.09$ пута (медијана 0). Анализирајући ове резултате Ман-Витнијевим У тестом утврђено је да нема статистички значајне разлика између стилова $(\mathrm{Z}=-1.479 ; \mathrm{p}=0.139)$.

Дистрибуција борби у односу на досуђена два бода у трећој рунди приказана је у табели 13.

Табела 13 Освајање 2 бода у трећој рунди по стиловима

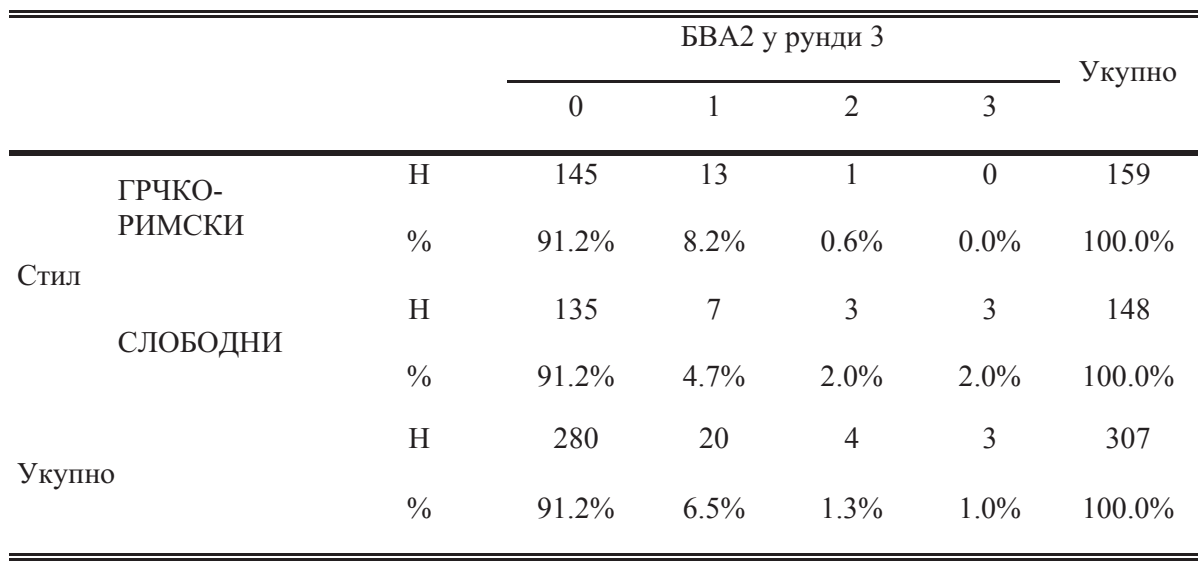

Из табеле се види да је дистрибуција давања два бода у трећој рунди готово идентична са малим варијацијама. Најчешће су, током треће рунде, у оба стила, два бода додељивана једном у целој рунди, грчко-римском стилу у $8.2 \%$ борби, а у слободном стилу у $4.7 \%$ борби. У грчко-римском стилу преовлађују борбе у којима током треће рунде уопште није било акција за 2 бода (91.2\% борби), док су само у 1 борби 2 бода додељена 2 пута (0.6\% борби). И у слободном стилу, друга рунда је без акције за 2 бода завршена у 91.2\% борби, али су 2 бода више од једанпут освајана у више борби (2 пута у $2 \%$ борби, а 3 пута такође у $2 \%$ борби).

У просеку, два бода су у трећој рунди дата $0.09 \pm 0,31$ пута по борби (медијана 0) у грчко-римском стилу, док су у слободном стилу, у просеку, два бода у трећој рунди досуђена $0.15 \pm 0.54$ пута (медијана 0 ). Анализирајући ове резултате Ман-Витнијевим У тестом утврђено је да нема статистички значајне разлика између стилова $(Z=-0.90 ; p=0.928)$. 
Рунда 3 - акције за 3 бода - БВАЗ

Дистрибуција борби у односу на дата три бода у трећој рунди приказана је у табели 14.

Табела 14 Освајање 3 бода у трећој рунди по стиловима

\begin{tabular}{|c|c|c|c|c|c|}
\hline & & & \multicolumn{2}{|c|}{ БВАЗ у рунди 3} & \multirow{2}{*}{ Укупно } \\
\hline & & & 0 & 1 & \\
\hline \multirow{4}{*}{ Стил } & \multirow{2}{*}{$\begin{array}{l}\text { ГРЧКО- } \\
\text { РИМСКИ }\end{array}$} & $\mathrm{H}$ & 154 & 5 & 159 \\
\hline & & $\%$ & $96.9 \%$ & $3.1 \%$ & $100.0 \%$ \\
\hline & \multirow{2}{*}{ СЛОБОДНИ } & $\mathrm{H}$ & 142 & 6 & 148 \\
\hline & & $\%$ & $95.9 \%$ & $4.1 \%$ & $100.0 \%$ \\
\hline \multirow{2}{*}{\multicolumn{2}{|c|}{ Укупно }} & $\mathrm{H}$ & 296 & 11 & 307 \\
\hline & & $\%$ & $96.4 \%$ & $3.6 \%$ & $100.0 \%$ \\
\hline
\end{tabular}

Аналогно претходном бодовању, из табеле се види да је дистрибуција бодовања готово идентична у оба стила, те не постоје статистички значајне разлике $(\mathrm{p}=0.764)$.

Рунда 3 - акције за 5 бодова - БВА5

У трећој рунди није било акција за пет бодова

Укупан број бодова у трећој рунди БПРЗ

Дескриптивна статистика укупног броја бодова у трећој рунди приказана је у табели 15.

Табела 15 Укупан број бодова у трећој рунди БПРЗ

\begin{tabular}{lcccccc}
\hline \hline Стил & $\begin{array}{c}\text { Аритметичка } \\
\text { средина }\end{array}$ & СД & Медиан & Минимум & Максимум & Сума \\
\hline $\begin{array}{l}\text { ГРЧКО- } \\
\text { РИМСКИ }\end{array}$ & .58 & 1.046 & .00 & 0 & 5 & 92 \\
СЛОБОДНИ & 1.00 & 1.863 & .00 & 0 & 9 & 148 \\
Укупно & .78 & 1.509 & .00 & 0 & 9 & 240 \\
\hline \hline
\end{tabular}

Из табеле се види да је просечна вредност акција које су бодоване у трећој рунди већа у слободном стилу. Исто се односи и на медијану, али је и варијабилитет већи у слободном стилу, као и укупна сума бодова. На основу резултата добијених Ман-Витнијевим У тестом, утврђено је да разлике у броју бодова освојених у трећој рунди у два стила рвања нису статистички значајне $(\mathrm{Z}=-1.118 ; \mathrm{p}=0.264)$. 
Укупан број бодова у борби УБП. Дескриптивна статистика бодова у целој борби (све три рунде) приказана је у табели 16.

Табела 16 Стил у односу на укупан број бодова у борби УБП

\begin{tabular}{lcccccc}
\hline \hline Стил & $\begin{array}{c}\text { Аритметичка } \\
\text { средина }\end{array}$ & СД & Медиан & Минимум & Максимум & Сума \\
\hline ГРЧКО- & 4.55 & 2.160 & 4.00 & 2 & 12 & 724 \\
РИМСКИ & 6.78 & 3.843 & 6.00 & 2 & 20 & 1004 \\
СЛОБОДНИ & 5.63 & 3.279 & 5.00 & 2 & 20 & 1728 \\
Укупно & & & & & & \\
\hline \hline
\end{tabular}

Просечна вредност бодова већа је у слободном стилу и износи 6.78 бодова по борби, при чему је медијана 6 бодова. Сума бодова је такође већа у слободном стилу, али је и варијабилитет већи у истом. У грчко-римском стилу је остварено укупно 724 бода, док је у слободном стилу освојено доста више, тј. 1004 бода. Минималан број остварених бодова је подједнак у оба стила и износи 2 бода, али је максималан број бодова у борби у грчко-римском стилу износио 12 , док је у слободном стилу максималан број бодова износио 20.

Анализирајући ове податке Ман-Витнијевим У тестом утврђено је да постоји статистички значајна разлика између стилова $(Z=-5.373 ; \mathrm{p}<0.001)$. 


\section{BPEME TPAJАњА БОРБЕ}

Време трајања борбе анализирано је по рундама и сумарно. Прво је приказано време по рундама.

Време трајања по рундама УТБ

Дескриптивна статистика трајања борбе по рундама приказана је у табели 17.

Табела 17 Време трајања борбе по рундама УТБ

\begin{tabular}{|c|c|c|c|c|c|c|c|c|}
\hline Време & Стил & $\mathrm{H}$ & $\begin{array}{l}\text { Аритметич } \\
\text { ка средина }\end{array}$ & СД & Медиан & Мин. & Макс. & $\begin{array}{c}\text { Значајност } \\
\text { разлика }\end{array}$ \\
\hline \multirow{3}{*}{ рунда 1} & $\begin{array}{l}\text { ГРЧКО- } \\
\text { РИМСКИ }\end{array}$ & 159 & 119.17 & 7.783 & 120.00 & 32 & 120 & \multirow{3}{*}{$\mathrm{p}=0.096$} \\
\hline & слОБОдни & 148 & 120.73 & 8.514 & 120.00 & 48 & 150 & \\
\hline & Укупно & 307 & 119.92 & 8.167 & 120.00 & 32 & 150 & \\
\hline \multirow{3}{*}{ рунда 2} & $\begin{array}{l}\text { ГРЧКО- } \\
\text { РИМСКИ }\end{array}$ & 159 & 119.06 & 7.130 & 120.00 & 42 & 120 & \multirow{3}{*}{$\mathrm{p}=0.205$} \\
\hline & слОБОдни & 147 & 117.26 & $\begin{array}{c}15.71 \\
1\end{array}$ & 120.00 & 21 & 150 & \\
\hline & Укупно & 306 & 118.19 & $\begin{array}{c}12.05 \\
4\end{array}$ & 120.00 & 21 & 150 & \\
\hline \multirow{3}{*}{ рунда 3} & $\begin{array}{l}\text { ГРЧКО- } \\
\text { РИМСКИ }\end{array}$ & 49 & 118.80 & 8.142 & 120.00 & 63 & 120 & \multirow{3}{*}{$\mathrm{p}=0.857$} \\
\hline & слОБОдни & 49 & 119.10 & 8.591 & 120.00 & 62 & 127 & \\
\hline & Укупно & 98 & 118.95 & 8.328 & 120.00 & 62 & 127 & \\
\hline
\end{tabular}

Просечно време трајања борбе је готово идентично у свакој рунди. Медијана је иста у свим рундама у оба стила. Анализирајући ове резултате утврђено је да у времену трајања борбе не постоје статистички значајне разлике између стилова. 
Сумарно време

Укупно време борбе је израчунато и дескриптивна статистика је приказана у табели 18.

Табела 18 Сумарно време борбе

\begin{tabular}{lrrrrr}
\hline \hline Стил & $\begin{array}{c}\text { Аритметичка } \\
\text { средина }\end{array}$ & СД & Медиан & Минимум & Максимум \\
\hline ГРЧКО- & 274.84 & 57.346 & 240.00 & 152 & 360 \\
РИМСКИ & 276.63 & 64.164 & 240.00 & 110 & 390 \\
СЛОБОДНИ & 275.70 & 60.635 & 240.00 & 110 & 390 \\
Укупно & & & & & \\
\hline \hline
\end{tabular}

Просечна вредност трајања меча је врло слична у оба стила и анализом је утврђено да нема статистички значајне разлике између њих $(\mathrm{Z}=-1.457$; $\mathrm{p}=0.145)$.

\section{ПОЕНИ У ПАРТЕРУ И СТОЈЕЪЕМ СТАВУ}

У даљој анализи испитивани су поени у стојећем ставу и поени у партеру.

Поени стојећи став - УБПСС

Дескриптивна статистика поена у стојећем ставу приказана је у табели 19.

Табела 19 Поени у стојећем ставу УБПСС

\begin{tabular}{lcccccc}
\hline \hline Стил & $\begin{array}{c}\text { Аритмети } \\
\text { чка } \\
\text { средина }\end{array}$ & СД & Медиан & Минимум & Максимум & Сума \\
\hline $\begin{array}{l}\text { ГРЧКО- } \\
\text { РИМСКИ }\end{array}$ & 1.46 & 2.006 & 1.00 & 0 & 10 & 232 \\
СЛОБОДНИ & 4.12 & 2.474 & 4.00 & 0 & 12 & 614 \\
Укупно & 2.74 & 2.606 & 2.00 & 0 & 12 & 846 \\
\hline \hline
\end{tabular}

Из стојећег става је направљено много више поена у слободном стилу него у грчко-римском, али је исто тако и варирање веће у истом стилу (Табела 19). Медијане су различите, у грчко-римском стилу је медијана 1, док је у слободном стилу медијана 4. Сума бодова је евидентно већа у слободном стилу. У грчко-римском стилу је укупно остварено 232 бода док је у слободном стилу освојено чак 614 бодова. Минималан број остварених бодова је подједнак у оба стила, што значи да је у оба стила било борби у којима у регуларном времену нису направљени бодови из стојећег става (минимум 0), док је максималан број бодова направљених из стојећег става у грчко-римском стилу износио 10, а у слободном стилу 12 
бодова. Сви добијени подаци недвосмислено потрвђују да је у слободном стилу из стојећег става направљено пуно више бодова него у грчко-римском стилу.

Ман-Витнијевим У тестом утврђено је да између стилова постоје статистички значајне разлике у броју бодова који су направљени у стојећем ставу $(\mathrm{Z}=-9.805 ; \mathrm{p}<0.001)$.

Поени - партер - УБПП

Аналогно поенима у стојећем ставу, приказана је и дескриптивна статистика поена у партеру (Табела 20).

Табела 20 Поени у партеру у односу на стил

\begin{tabular}{lcccccc}
\hline \hline Стил & $\begin{array}{c}\text { Аритметичка } \\
\text { средина }\end{array}$ & СД & Медиан & Минимум & Максимум & Сума \\
\hline $\begin{array}{l}\text { ГРЧКО- } \\
\text { РИМСКИ }\end{array}$ & 2.83 & 1.707 & 3.00 & 0 & 9 & 450 \\
СЛОБОДНИ & 1.95 & 2.554 & 1.00 & 0 & 11 & 289 \\
Укупно & 2.41 & 2.198 & 2.00 & 0 & 11 & 739 \\
\hline \hline
\end{tabular}

Насупрот поенима из стојећег става, из партера је у грчко-римском стилу прављено знатно више поена, па је и просечан број бодова освојених у партеру већи у грчко-римском него у слободном стилу, али је исто тако и варирање веће у истом стилу (Табела 20). Медијане су различите, у грчко-римском стилу медијана је 3, док је у слободном стилу медијана 1. Сума бодова евидентно је већа у грчко-римском стилу. У грчко-римском стилу је укупно остварено 450 бодова, док је у слободном стилу освојено свега 289 бодова. Минималан број остварених бодова је подједнак у оба стила и износи 0 бодова, док је максималан број бодова остварених из партера у грчко-римском стилу био 9 , док је у слободном стилу износио 11 бодова.

Ман-Витнијевим У тестом утврђено је да између стилова постоје статистички значајне разлике у броју бодова који су направљени у партеру $(\mathrm{Z}=-5.454 ; \mathrm{p}<0.001)$.

Број бодова у обавезном партеру, партер одбрана и напад - ОБО, ОБП

Број бодова у обавезном партеру, партер одбрана и напад анализирана је у грчко-римском стилу. Дескриптивна статистика наведених параметара приказана је у табели 21.

табела 21 Број бодова из обавезног партера, одбрана и напад

\begin{tabular}{lcccccc}
\hline \hline & $\begin{array}{c}\text { Аритметичка } \\
\text { средина }\end{array}$ & СД & Медиан & Минимум & Максимум & Сума \\
\hline $\begin{array}{l}\text { Обавезни партер - } \\
\text { одбрана }\end{array}$ & .88 & .790 & 1.00 & 0 & 3 & 140 \\
Обавезни партер - напад & 1.65 & 1.684 & 2.00 & 0 & 9 & 262 \\
Обавезни партер -укупно & 2.53 & 1.753 & 3.00 & 0 & 9 & 402 \\
\hline \hline
\end{tabular}


Број бодова у партеру из борбе

Дескриптивна статистика бодова у партеру из борбе приказана је у табели 22.

Табела 22 Број бодова у партеру из борбе

\begin{tabular}{lcccccc}
\hline \hline Стил & $\begin{array}{c}\text { Аритмет. } \\
\text { средина }\end{array}$ & СД & Медиан & Минимум & Максимум & Сума \\
\hline $\begin{array}{l}\text { ГРЧКО- } \\
\text { РИМСКИ }\end{array}$ & .30 & .953 & .00 & 0 & 6 & 48 \\
СЛОБОДНИ & 1.95 & 2.554 & 1.00 & 0 & 11 & 289 \\
Укупно & 1.10 & 2.070 & .00 & 0 & 11 & 337 \\
\hline \hline
\end{tabular}

Ако се изузму бодови из обавезног партера, у слободном стилу је у партеру направљен већи број бодова. Просечан број бодова је нешто већи у слободном стилу, али је исто тако и варирање веће у истом стилу. Медијане су различите, у грчко - римском стилу медијана је 0 , док је у слободном стилу медијана 1. Минималан број остварених бодова је подједнак у оба стила и износи 0 бодова, док је максималан број бодова у партеру из борбе у грчко-римском стилу био 6, док је у слободном стилу био 11 бодова (табела 22). Ако се има у виду чињеница да у слободном стилу не постоји такозвани обавезни део борбе у партеру, онда овакви резултати уопште нису у супротности са претходно презентованим резултатима о укупном броју бодова у партеру. Наиме, у слободном стилу су сви бодови из партера направљени након акција којима је противник доведен у партерни положај, док је у грчко-римском већина партерних техника пласирана у периоду борбе када је противник био обавезан да заузме партерни положај. Због свега тога, није изненађење што је у слободном стилу, ако се изузму бодови из обавезног партера, направљен значајно већи број бодова из партера. Ове разлике показују и велику статистичку значајност $(\mathrm{Z}=-7.800 ; \mathrm{p}<0.001)$.

\section{ИНТЕНЗИТЕТ БОРБЕ - ИБ}

Интензитет борбе, који подразумева време које је у просеку потребно да се направи један поен, посматран је сумарно и по рундама.

Сумарни интензитет борбе

Дескриптивна статистика сумарног интензитета борбе приказана је у табели 23.

Табела 23 Сумарни интензитет борбе по стиловима

\begin{tabular}{lccccc}
\hline \hline Стил & Арит. средина & СД & Медиан & Максимум & Минимум \\
\hline ГРЧКО- & 72.05 & 30.19 & 72 & 20.25 & 179 \\
РИМСКИ & & & & & 135 \\
СЛОБОДНИ & 55.52 & 33.67 & 48 & 10.88 & 179 \\
Укупно & 64.05 & 32.93 & 60 & 10.88 & \\
\hline \hline
\end{tabular}


Интензитет борбе, који је представљен просечним временом потребним за остваривање једног бода, много је већи у слободном стилу него у грчко-римском (Табела 23). Аритметичка средина интензитета борбе у грчко-римском стилу износи 72.05 , док је у слободном стилу износио 55.52. Максимални интезитет борбе у грчко-римском стилу је износио је 20.25 , док је у најинтензивнијој борби у слободном стилу за прављење једног бода било потребно свега 10.88 секунди, па је интензитет износио 10.88 . Минимални интезитет борбе је у грчко-римском стилу износио 179, у слободном стилу износио је 135. Медијана у грчко-римском стилу износила је 72, а у слободном 48. На основу свега могуће је закључити да је сумарни интензитет борбе статистички значајно већи у слободном стилу $(Z=-4.996 ; p<0.001)$.

Интензитет борбе у првој рунди ИБ1

Аналогно претходним анализама, интетзитет борбе је анализиран и по рундама и дескриптивна статистика у односу на стилове је приказана у табели 24.

Табела 24 Интензитет борбе у првој рунди - ИБ1

\begin{tabular}{lccccc}
\hline \hline Стил & $\begin{array}{c}\text { Аритметичка } \\
\text { средина }\end{array}$ & СД & Медиан & Максимум & Минимум \\
\hline ГРЧКО- & 79.48 & 38.634 & 60.00 & 5 & 120 \\
РИМСКИ & 71.97 & 44.414 & 60.00 & 8 & 150 \\
СЛОБОДНИ & 75.86 & 41.622 & 60.00 & 5 & 150 \\
Укупно & & & & & \\
\hline \hline
\end{tabular}

Мада је максимални интензитет борбе у првој рунди забележен у грчко-римском стилу, јер је у једној борби у просеку било потребно свега 5 секунди за прављење 1 бода, ипак је просечни интензитет борбе већи у слободном стилу (Табела 24). Варијабилитет је већи у слободном стилу, док су медијане исте. Анализирајући ове податке Ман-Витнијевим У тестом, утврђено је да нема статистички значајне разлике између стилова ( $\mathrm{Z}=-1.067 ; \mathrm{p}=0.286)$.

Интензитет борбе у другој рунди - ИБ2

Дескриптивна статистика интензитета борбе у другој рунди приказана је у табели 25.

табела 25 Интензитет борбе у другој рунди - ИБ2

\begin{tabular}{lccccc}
\hline \hline Стил & $\begin{array}{c}\text { Аритметичка } \\
\text { средина }\end{array}$ & СД & Медиан & Максимум & Минимум \\
\hline ГРЧКО- & 85.59 & 38.357 & 120.00 & 7 & 120 \\
РИМСКИ & 63.52 & 43.485 & 60.00 & 6 & 150 \\
СЛОБОДНИ & 74.99 & 42.300 & 60.00 & 6 & 150 \\
Укупно & & & & & \\
\hline \hline
\end{tabular}

И у другој рунди интензитет борбе је значајно већи у слободном стилу него у грчко-римском стилу, при чему је и максимални забележени интензитет у некој борби већи у слободном стилу (Табела 25). Евидентна је и разлика медијана, која је далеко већа него разлика између аритметичких средина. На основу свега може се констатовати да је у слободном стилу интензитет борбе у другој рунди статистички значајно већи него у грчко-римском стилу $(\mathrm{Z}=-4.071 ; \mathrm{p}<0.001)$. 
Интензитет борбе у трећој рунди - ИБЗ

Дескриптивна статистика интензитета борбе у трећој рунди по стиловима приказана је у табели 26.

табела 26 Интензитет борбе у трећој рунди - ИБЗ

\begin{tabular}{lcccccc}
\hline \hline Стил & Н & $\begin{array}{c}\text { Аритметичка } \\
\text { средина }\end{array}$ & СД & Медиан & Максимум & Минимум \\
\hline $\begin{array}{l}\text { ГРЧКО- } \\
\text { РИМСКИ }\end{array}$ & 48 & 82.60 & 37.669 & 60.00 & 21 & 120 \\
СЛОБОДНИ & 48 & 61.69 & 39.423 & 60.00 & 10 & 124 \\
Укупно & 96 & 72.15 & 39.767 & 60.00 & 10 & 124 \\
\hline \hline
\end{tabular}

Разлика просечних вредности је слична као у претходној ситуацији, али су у овом случају медијане исте. Анализирајући ове податке Ман-Витнијевим У тестом утврђено је да је интензитет борбе у трећој рунди у слободном стилу статистички значајно већи него у грчко-римском $(\mathrm{Z}=-2.371 ; \mathrm{p}=0.018)$.

Клинч у слободном стилу КН, КО

Дистрибуција бодова у односу на клинч у Слободном стилу приказана је у табели 27.

табела 27 Клинч

\begin{tabular}{|c|c|c|c|}
\hline & & $\mathrm{H}$ & $\%$ \\
\hline \multirow{5}{*}{ KH } & 0 & 110 & $74.3 \%$ \\
\hline & 1 & 22 & $14.9 \%$ \\
\hline & 2 & 8 & $5.4 \%$ \\
\hline & 3 & 7 & $4.7 \%$ \\
\hline & 5 & 1 & $0.7 \%$ \\
\hline \multirow{4}{*}{ КО } & 0 & 141 & $95.3 \%$ \\
\hline & 1 & 5 & $3.4 \%$ \\
\hline & 2 & 1 & $0.7 \%$ \\
\hline & 3 & 1 & $0.7 \%$ \\
\hline \multirow{5}{*}{$\begin{array}{l}\text { Бодови - } \\
\text { клинч }\end{array}$} & 0 & 104 & $70.3 \%$ \\
\hline & 1 & 26 & $17.6 \%$ \\
\hline & 2 & 8 & $5.4 \%$ \\
\hline & 3 & 9 & $6.1 \%$ \\
\hline & 5 & 1 & $0.7 \%$ \\
\hline
\end{tabular}




\section{OПОМЕНЕ - БО}

У оквиру анализе опомена, посматрана је сума опомена, интензитет и да ли се ради о опомени у партеру или стојции.

Дистрибуција у борби по суми опомена у односу на стилове приказана је у табели 28.

Табела 28 Број борби у којима је досуђена 1, 2 или 3 опомене

\begin{tabular}{|c|c|c|c|c|c|c|c|c|}
\hline & & & \multicolumn{4}{|c|}{ Сума опомена } & \multirow{2}{*}{ Укупно } & \multirow{2}{*}{$\begin{array}{c}\text { Сума } \\
\text { опомена }\end{array}$} \\
\hline & & & 0 & 1 & 2 & 3 & & \\
\hline \multirow{4}{*}{ Стил } & \multirow{2}{*}{$\begin{array}{l}\text { ГРЧКО- } \\
\text { РИМСКИ }\end{array}$} & $\mathrm{H}$ & 139 & 16 & 2 & 2 & 159 & \multirow{2}{*}{26} \\
\hline & & $\%$ & $87.4 \%$ & $10.1 \%$ & $1.3 \%$ & $1.3 \%$ & $100.0 \%$ & \\
\hline & \multirow{2}{*}{ сЛОБОДНИ } & $\mathrm{H}$ & 141 & 7 & 0 & 0 & 148 & \multirow[b]{2}{*}{7} \\
\hline & & $\%$ & $95.3 \%$ & $4.7 \%$ & $0.0 \%$ & $0.0 \%$ & $100.0 \%$ & \\
\hline \multirow{2}{*}{\multicolumn{2}{|c|}{ Укупно }} & $\mathrm{N}$ & 280 & 23 & 2 & 2 & 307 & \multirow{2}{*}{33} \\
\hline & & $\%$ & $91.2 \%$ & $7.5 \%$ & $0.7 \%$ & $0.7 \%$ & $100.0 \%$ & \\
\hline
\end{tabular}

У грчко-римском стилу нешто је већи проценат борби у којима је опомена досуђена једном, док је у слободном стилу било нешто више борби без опомена (Табела 28), а разлике између стилова по суми опомена су статистички значајне $(\mathrm{Z}=-2.458 ; \mathrm{p}=0.014)$.

\section{Интензитет опомена}

Дескриптивна статистика интензитета опомена код борби у којима је било опомена приказана је у табели 29.

Табела 29 Интензитет опомена

\begin{tabular}{lcccccc}
\hline \hline Стил & Н & $\begin{array}{c}\text { Аритметичка } \\
\text { средина }\end{array}$ & СД & Медиан & Минимум & Максимум \\
\hline $\begin{array}{l}\text { ГРЧКО- } \\
\text { РИМСКИ }\end{array}$ & 20 & 259.90 & 87.492 & 240.00 & 98 & 360 \\
СЛОБОДНИ & 7 & 262.29 & 56.337 & 240.00 & 240 & 390 \\
Укупно & 27 & 260.52 & 79.546 & 240.00 & 98 & 390 \\
\hline \hline
\end{tabular}

Из табеле се види да се ради о врло сличном интензитету опомена, једино је разлика у варијабилитету, који је нешто већи у грчко-римском стилу.

Анализирајући ове податке Ман-Витнијевим У тестом утврђено је да нема статистички значајне разлике између стилова $(\mathrm{Z}=-0.593 ; \mathrm{p}=0.607)$. 
Опомене у партеру и стојећем ставу

У партеру је укупно било 14 опомена и све су биле у грчко-римском стилу. Једна опомена била је у 13 борби $(92.9 \%)$, док су две опомене биле у једној борби (7.1\%).

Дистрибуција опомена у стојећем ставу у односу на стилове приказана је у табели 30 .

табела 30 Опомене у стојећем ставу

\begin{tabular}{|c|c|c|c|c|c|}
\hline & & & \multicolumn{2}{|c|}{ Опомена стојећи } & \multirow{2}{*}{ Укупно } \\
\hline & & & 1 & 2 & \\
\hline \multirow{4}{*}{ Стил } & \multirow{2}{*}{$\begin{array}{l}\text { ГРЧКО- } \\
\text { РИМСКИ }\end{array}$} & $\mathrm{H}$ & 5 & 3 & 8 \\
\hline & & $\%$ & $62.5 \%$ & $37.5 \%$ & $100.0 \%$ \\
\hline & \multirow{2}{*}{ сЛОБОДНИ } & $\mathrm{H}$ & 7 & 0 & 7 \\
\hline & & $\%$ & $100.0 \%$ & $0.0 \%$ & $100.0 \%$ \\
\hline \multirow{2}{*}{\multicolumn{2}{|c|}{ Укупно }} & $\mathrm{H}$ & 12 & 3 & 15 \\
\hline & & $\%$ & $80.0 \%$ & $20.0 \%$ & $100.0 \%$ \\
\hline
\end{tabular}

Мада разлике нису статистичке значајне ( $\mathrm{p}=0.200)$, уочљиво је да у грчко-римском стилу има неколико борби са две опомене док у слободном није забележена ниједна таква борба.

Начин победе

Дистрибуција борби у односу на начин победе приказана је у табели 31.

табела 31 Начин победе

\begin{tabular}{|c|c|c|c|c|c|c|c|}
\hline & & & \multicolumn{4}{|c|}{ Начин победе } & \multirow{2}{*}{ Укупно } \\
\hline & & & На поене & туш & тех.туш & прекид & \\
\hline \multirow{4}{*}{ Стил } & \multirow{2}{*}{$\begin{array}{l}\text { ГРЧКО- } \\
\text { РИМСКИ }\end{array}$} & $\mathrm{H}$ & 152 & 1 & 1 & 1 & 155 \\
\hline & & $\%$ & $98.1 \%$ & $0.6 \%$ & $0.6 \%$ & $0.6 \%$ & $100.0 \%$ \\
\hline & \multirow{2}{*}{ сЛОБОДНИ } & $\mathrm{H}$ & 143 & 3 & 1 & 0 & 147 \\
\hline & & $\%$ & $97.3 \%$ & $2.0 \%$ & $0.7 \%$ & $0.0 \%$ & $100.0 \%$ \\
\hline \multirow{2}{*}{\multicolumn{2}{|c|}{ Укупно }} & $\mathrm{H}$ & 295 & 4 & 2 & 1 & 302 \\
\hline & & $\%$ & $97.7 \%$ & $1.3 \%$ & $0.7 \%$ & $0.3 \%$ & $100.0 \%$ \\
\hline
\end{tabular}

Из табеле се види да је дистрибуција у обе групе врло слична и да је у готово свим борбама начин победе био НП (Х2=2.064; $\mathrm{p}=0.678)$. 
Бод челенџ - БЧ

Као последње, урађена је анализа између група по боду добијеном из челенџа. Дистрибуција борби у односу на бод из челенџа по стиловима приказана је у табели 32.

Табела 32 Бод из челениа

\begin{tabular}{|c|c|c|c|c|c|c|}
\hline & & & \multicolumn{3}{|c|}{ БЧ } & \multirow{2}{*}{ Укупно } \\
\hline & & & 0 & 1 & 2 & \\
\hline \multirow{4}{*}{ Стил } & \multirow{2}{*}{$\begin{array}{l}\text { ГРЧКО- } \\
\text { РИМСКИ }\end{array}$} & $\mathrm{H}$ & 126 & 32 & 1 & 159 \\
\hline & & $\%$ & $79.2 \%$ & $20.1 \%$ & $0.6 \%$ & $100.0 \%$ \\
\hline & \multirow{2}{*}{ сЛОБОДНИ } & $\mathrm{H}$ & 124 & 20 & 4 & 148 \\
\hline & & $\%$ & $83.8 \%$ & $13.5 \%$ & $2.7 \%$ & $100.0 \%$ \\
\hline \multirow{2}{*}{\multicolumn{2}{|c|}{ Укупно }} & $\mathrm{H}$ & 250 & 52 & 5 & 307 \\
\hline & & $\%$ & $81.4 \%$ & $16.9 \%$ & $1.6 \%$ & $100.0 \%$ \\
\hline
\end{tabular}

Јасно је да је дистрибуција бодова из челенџа врло слична у оба стила, па не постоје статистички значајне разлике између група $(\mathrm{X} 2=0.240 ; \mathrm{p}=0.701)$.

\section{4. Закључци}

Сам назив овог рада (Компарација такмичарске активности рвача грчко-римским и слободним стилом) говори да се ради о компаративној статистици у којој има више варијабли које се међусобно упоређују. Прикупљање података у овом истраживању трансверзалног карактера извршено је методом опсервације, тј. анализом података са такмичења, при чему су кориштени видео материјали свих борби са Олимпијских игара у Лондону 2012. године.

Узорак истраживања предстаљају све борбе које су, на Олимпијским играма у Лондону 2012. године, одржане у рвању грчко-римским и слободним стилом за мушкарце у 7 тежинских категорија, укупно 316 борби. У грчко-римском стилу учествовало је 135 такмичара, а одржано је и обрађено укупно 159 борби, док је у слободном стилу учествовало 133 такмичара, а одржано је и обрађено 157 борби.

Базирајући се на претходним подацима који су условили и избор примерених методолошких поступака дескриптивне, експлоративне и инференцијалне статистике, извршено је испитивање и доказивање постављених хипотеза.

$\mathrm{X1:} \mathrm{Укупан} \mathrm{број} \mathrm{успешних} \mathrm{акција} \mathrm{значајно} \mathrm{се} \mathrm{разликује} \mathrm{у} \mathrm{грчко-римском} \mathrm{и} \mathrm{слободном} \mathrm{стилу.}$

Код испитивања ове хипотезе, која је била постављена тако да ово истраживање потврди хипотезу да се број успешних акција значајно разликује у грчко-римском и слободном стилу, генерални закључак је да се ова хипотеза одбацује. Но, због појављивања појединачних значајних веза по појединим рундама, ово испитивање би требало наставити у наредним истраживањима.

Х2: Укупан број освојених бодова значајно се разликује у грчко-римском и слободном стилу. 
Ова хипотеза је потврђена, будући да добијени резултати показују да је просечна вредност бодова већа је у слободном стилу, као и медијана. Сума бодова је такође већа у слободном стилу, али је и варијабилитет већи у истом. Анализирајући ове податке Ман-Витнијевим У тестом утврђено је да постоји статистички значајна разлика између стилова.

Х3: Просечан број успешно реализованих акција по минути борбе значајно се разликује у грчко-римском и слободном стилу.

X4: Просечан број остварених бодова по минути борбе значајно се разликује у грчко - римском и слободном стилу.

Ова хипотеза је потврђена јер на основу резултата види се да постоји значајна разлика у корист грчкоримског стила, када је у питању број остварених бодова по минути борбе.

X5: Број остварених бодова из стојећег става и партера значајно се разликује у грчко - римском и слободном стилу.

Ова хипотеза је потврђена и види се да је просечна вредност поена у стојећем ставу већа у слободном стилу. Анализирајући ове податке Ман-Витнијевим У тестом утврђено је да постоји статистички значајна разлика између стилова, док у партеру насупрот поенима из стојећег става, просечна вредност је већа у грчко-римском стилу.

Х6: Укупан број јавних опомена значајно се разликује у грчко-римском и слободном стилу.

X7: Број „челенџа“ значајно се разликује у грчко-римском и слободном стилу.

Ова хипотеза није потврђена будући да је дистрибуција бодова из челенџа врло слична у оба стила, па не постоје статистички значајне разлике између група.

X8: Укупно трајање свих борби значајно се разликује у грчко-римском и слободном стилу.

Ова хипотеза није потврђена будући да је просечна вредност трајања меча врло слична у оба стила и анализом је утврђено да нема статистички значајне разлике између њих.

X9: Начин остваривања победе значајно се разликује у грчко-римском и слободном стилу.

Ова хипотеза није потврђена јер из табеле се види да је дистрибуција у обе групе врло слична и да је у готово свим борбама начин победе био НП.

Х10: Бодовна структура реализованих акција значајно се разликује у грчко - римском и слободном стилу.

\section{5. Литература}

Бербером, Н., Ставрев, И. (1984). Руководство по класическата борба. Софија: ВИФ.

Ћирковић, З., Јованович, С., Касум, Г. (2008). Народно и спортско рвање. Београд: Универзитет у Београду ФСФВ.

Ћирковић, 3., Касум, Г.(2000). Рвање грчко-римским стилом. Београд: ЈУДО магазин.

Докманац, М. (1996). Анализа Олимпијског турнира у рвању - Атланта 1996. Београд: РСС.

Докманац, М. (2000). Компарација резултата постигнутих на светским првенствима у рвањугрчкоримским стилом 1997. и 1998.године. Непубликовани магистарски рад, Универзитет у Београду, Факултет физичке културе.

Докманац, М. (2010). Такмичарске технике врхунских светских рвача. Нови Сад: Покрајински завод за спорт.

Група аутора (1976). Дие Олумпиасиегер им гриецмицх-ромисцхен Ринген вон 1896-1972. Карсрухе:Ин Атлетик. 
Јовановић, Копривица, Ћирковић и Коропановски, 2010). Теоријски приступ истраживању моделних карактеристика такмичарске активности у борилачким спортовима. У Међународна научна конференција: Физичка активност за свакога, Зборник радова (269-273). Београд: Универзитет у Београду Факултет спорта и физичког васпитања.

Касум, Г. (2006). Еволуција рвачких правила.У Други научно-стручни међународни симпозијум „Модели тренажног процеса у борилачким спортовима“ - Зборник радова (21-32). Панчево: Покраински завод за спорт и Скупштина општине Панчево.

Касум Г., Ћирковић 3., Јовановић С. (2012). Рвање. Београд: Универзитет у Београду ФСФВ.

Кецман, М. (2013). Монографија 90 година Рвачог клуба „Раднички“. Београд: Рвачки клуб Раднички.

Колунџија, Д. (1998). Рвање у Југославији. Београд: РСС.

Киров, П., Макаеев, О. (2010). Спортна подготовка на бореца. Софија.

Мрков, Г. ( 2003). Основи на спортната борба. Софија: Висше транспортно училишће „Тодор Коблешков“"

Петров, Р. 1977). Принципи на слободнијат стил и класическа борба на адолесценти и јуноши. Пловдив.

Петров, Р. (2005). Азбуката на борбата. Софија.

Подливајев, В. (1999). Анализ на чемпионата на европеиски првенства и олипииски игри. Москва: ФБР.

Савас, Л.К. (2003). Основи на класическа борба. Софија.

Сахмурадов., А. (1997). Анализа ОИ 1192 и 1996. Москва: ФБР.

Ставрев, И., Димитров, Н., Станчев, Н. (2008). Руководство по борба за учители. Софија.

Стефановић, Ђ. (2011). Философија, наука, теорија и пракса спорта. Београд: Универзитет у Београду Факултет спорта и физичког васпитања.

Tuenneman, H. (1997). Anallysis of the World championship 1997 year in freestyle and Greco-romane wrestling. Lozana: FILA.

Tuenneman, H. (1998). Anallysis of the World championship 1998 year in freestyle and Greco-romane wrestling. Lozana: FILA.

Tuenneman, H. (2004). Anallysis of the World championship 1976-2004 year in freestyle and Greco-romane wrestling. Lozana: FILA.

Org. Com Olipic Games 2012 (2012). Oficijalni bilten Olimpic Games 2012. London: Org. Com.

www.fila-wrestling.com. 